\title{
Opportunistic ship-based census of pack ice seals in eastern Weddell Sea, Antarctica
}

\author{
Marthán N. Bester ${ }^{{ }^{*}}$, Mia Wege ${ }^{1}$, Nico Lübcker ${ }^{1}$, Martin Postma ${ }^{1}$, and Gavin \\ Syndercombe ${ }^{2}$ \\ ${ }^{1}$ Mammal Research Institute, Department of Zoology and Entomology, University of \\ Pretoria, Private Bag X20, Hatfield 0028, South Africa \\ ${ }^{2}$ SMIT Amandla Marine, PO Box 1339, Cape Town 8000, South Africa \\ *Corresponding author: +27(0)726015470; +27(0)124202534 (fax); \\ mnbester@zoology.up.ac.za; u02330946@up.ac.za
}

\begin{abstract}
The distribution, density and percentage contribution of pack ice pinnipeds during shipboard censuses in the eastern Weddell Sea in summer 2015/16 are presented. Of the four true pack ice seal species encountered, crabeater seals predominated. Despite the low survey effort, Ross seals continued to be relatively abundant in the pack ice off the Princess Martha Coast in mid-January 2016, similar to the situation here in the 1970s. Censusing of Ross seals is ideally carried out in late January/early February when the species' haulout probability is at its maximum and the seals are gathered in the limited summer pack ice to moult.
\end{abstract}

Keywords: Pack ice seals, Ross seals, crabeater seals, eastern Weddell Sea, shipboard censuses, austral summer 2015/16.

\section{Introduction}

A comprehensive review of data on abundance, trends in abundance, habitat use and diet of ice-breeding seals in the Southern Ocean (Southwell et al. 2012) highlights the dearth of information that impedes conservation management in the Southern Ocean. The Ross seal (Ommatophoca rossii) is the least numerous and least studied of the 
Antarctic ice-breeding phocids (Bester 2014). The total estimated abundance of pack ice seals through aerial census, between 1995 and 2001, in the area between 20\% and $5^{\circ} \mathrm{E}$, were 514,000 crabeater seals (Lobodon carcinophaga), 60,000 Weddell seals (Leptonychotes weddellii), 13,200 leopard seals (Hydrurga leptonyx) and only 830 Ross seals (Gurarie et al. 2017).

Despite the varying detection probability of pack ice seals (Southwell et al. 2012), Ross seals were found in relatively high numbers, during 1974-1977 (Condy 1977) in the inshore waters off Penguin Bukta $\left(70^{\circ} 15.77^{\prime} \mathrm{S}, 02^{\circ} 42.88 \mathrm{~W}\right)$, in the eastern Weddell Sea, compared to Ross seal densities observed in six regions of Antarctic pelagic pack ice (Erickson and Hanson 1990). Ross seal abundance also increased progressively from west to east in the pack ice of the eastern Weddell Sea (Condy 1977, Bester and Odendaal 2000, Bester et al. 2002). The area covered by the aforementioned surveys

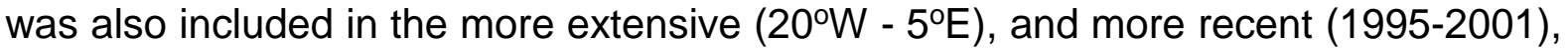
Gurarie et al. (2017) aerial surveys (see above).

Relatively low densities of Ross seals found in the 1991/92 survey (Bester et al. 1995), compared to the surveys in the 1970s (Condy 1977), and anecdotal claims of an overall paucity of pack ice seals on the inbound and outbound tracks of the MV SA Agulhas II since 2012, prompted the present observations. These observations were done in tandem with the investigation of ranging and diving behaviour of Ross seals through the deployment of satellite-linked data loggers on temporarily restrained animals (unpublished MRI data).

This note deals with the distribution, density and percentage contribution of Ross seals, compared to the other pack ice pinnipeds encountered on the cruise track of the MV SA Agulhas II, between 2446.8'W and $0^{\circ} 43.2^{\prime} \mathrm{W}$ longitude in the eastern Weddell Sea during December 2015 to February 2016.

\section{Materials and methods}

Ship-board surveys of pack-ice seals were conducted from an elevation of $23 \mathrm{~m}$ standing on the bridge of the MV SA Agulhas II as the vessel transited the pack ice 
to/from Penguin Bukta (70¹5.77'S, 0242.88'W) in austral summer 2015/16 (Fig. 1). Censuses were conducted while the ship was underway, between $10 \mathrm{~h} 00$ and 15h00 local time, which covers the peak haulout period of both crabeater seals (Erickson et al.1989) and Ross seals (Blix and Nordøy 2007). The census strip widths were $200 \mathrm{~m}$ to either side of the ship track (400m total width). Strip boundaries were determined using sighting boards (Siniff et al. 1970); we assumed no noteworthy undercounting given the narrow strip censused from the ship.

There were four observers aboard who observed from the wings of the ship's bridge, two observers at a time, and rotating on a 2-3 h schedule. The ship's position was recorded every 15 min from the ship's GPS navigational system. Seals were identified to species following Laws (1993). Ice coverage was classified (in tenths) following Erickson et al. (1993), and predominant cover estimated over 15 min intervals of travel.

A constant vigil by one observer, rotating with the 3 others in three to four hour shifts, was also maintained outside of the survey period of Leg 1 (see Results) to identify any seals within sight of the ship, in particular Ross seals, to ascertain their presence in the early (December) season.

\section{Results}

The ship first encountered the northern edge of the open ice pack on 11 December 2015, at 56 $15.6^{\prime} \mathrm{S}, 00^{\circ} 0^{\prime} \mathrm{W}$, on the way to the ice shelf on the Princess Martha Coast, Antarctica (Fig. 1A). Three days after the arrival at Penguin Bukta on 16 December, the ship departed westward to Atka Bay $\left(70^{\circ} 30.54^{\prime} \mathrm{S}, 08^{\circ} 10.93^{\prime} \mathrm{W}\right)$, remained there for two days, then headed for Southern Thule $\left(59^{\circ} 25^{\prime} 16^{\prime \prime S} 27^{\circ} 13^{\prime} 49^{\prime \prime} \mathrm{W}\right)$, South Sandwich Islands, on 22 December, arriving 28 December (Fig. 1A). At the time, the northern boundary of the pack ice near Southern Thule was at $59^{\circ} 11.73 \mathrm{~S}, 27^{\circ} 51.89^{\prime} \mathrm{W}$. Vigil for pack ice seals was terminated on 27 December at $60^{\circ} 44.51^{\prime} \mathrm{S}, 26^{\circ} 12.28^{\prime} \mathrm{W}$. At the start of the ship-board survey (Leg 1) on 12 December 2015, the N-S ice extent in the surveyed area was estimated to be circa $842 \mathrm{~nm}(1558 \mathrm{~km})$, about 21 times the extent $(\sim 40 \mathrm{~nm})$ at the start of Leg 2 (Fig. 1B), one month later on 12 January 2016. 

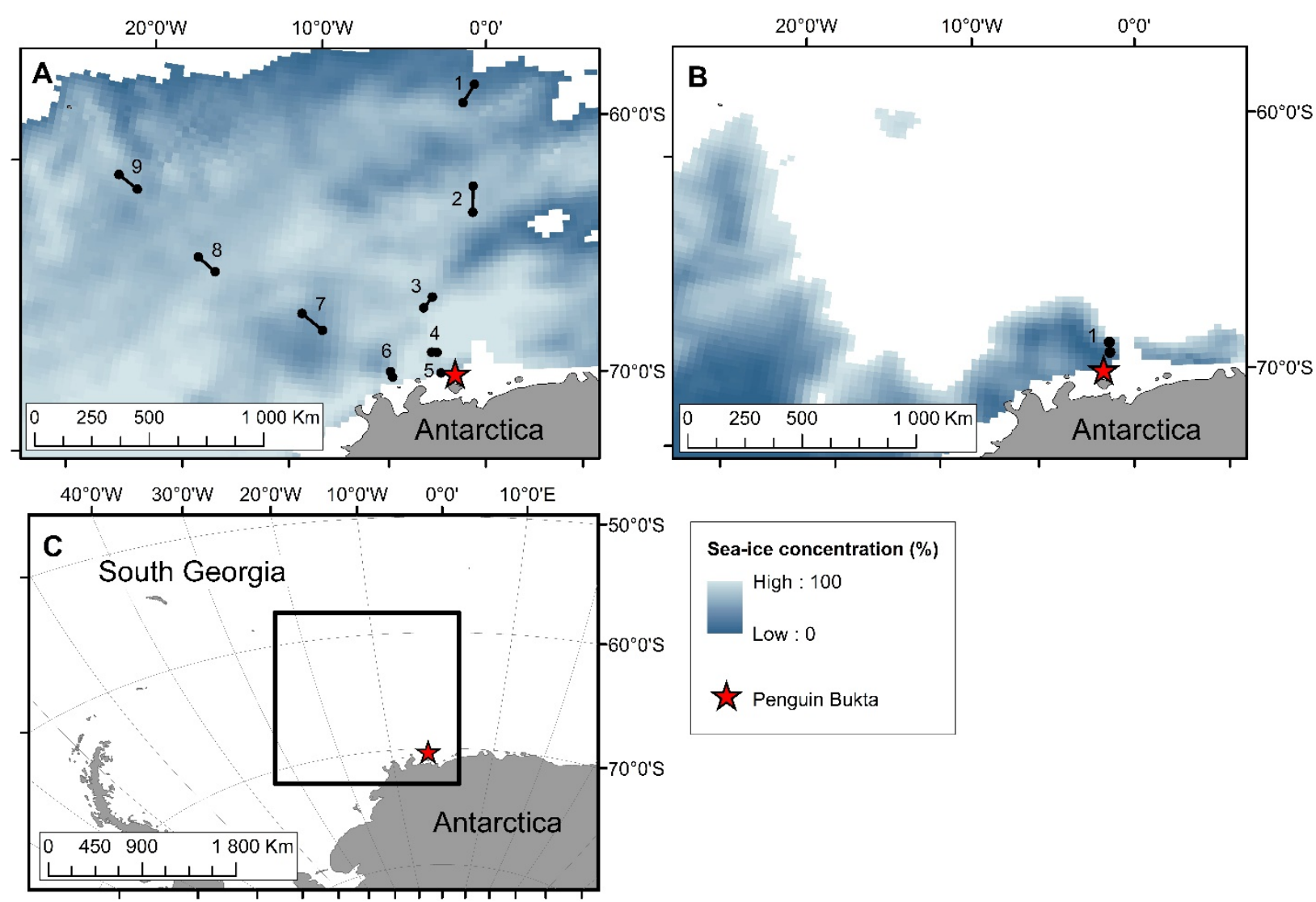

Figure 1: Location of ship-board censuses during leg 1 (A) to and from Penguin Bukta in December 2015, and leg 2 (B) to Penguin Bukta from the adjacent outer edge of the pack ice in mid-January 2016. Censuses were conducted during the peak diel haulout period of Ross seals, and the starting and ending positions of the sequentially numbered censuses are i ndicated (numbered black solid lines). The location of the census area within the eastern Weddell sea is shown (C). Sea-ice concentration data is at a $25 \times 25$ $\mathrm{km}$ resolution and was obtained from the NASA Nimbus-7 SMMR and DMSP SSM/ISSMIS Passive Microwave Data, Version 1 (Cavalieri et al. 1996). 
Ship- board censuses - Leg 1

A total of 321 linear nm (594.63 km) of transect was surveyed during nine ship-board censuses on Leg 1 (Fig. 1A), during which only 50 crabeater seals (100\%) were observed at a mean density of $1.03 \pm 1.47 \mathrm{~nm}^{-2}$. Pack-ice cover varied widely, from large stretches of open water to consolidated pack. The mean pack ice cover (mean \pm standard deviation) was $47.0 \pm 40.0 \%$ (range: $0-100 \%$ ).

Outside of the strip transect and/or during off-peak hours, some crabeater seals, one Weddell seal (15 December, 69²8.2'S, 0403.1'W), one leopard seal (27 December, $61^{\circ} 46.8 \mathrm{~S}, 2^{\circ} 16.9^{\prime} \mathrm{W}$ ), one southern elephant seal (Mirounga leonina) on 27 December $\left(62^{\circ} 22.8^{\prime} \mathrm{S}, 2^{\circ} 53.6^{\prime} \mathrm{W}\right.$ ) and two Ross seals (24 and 27 December;

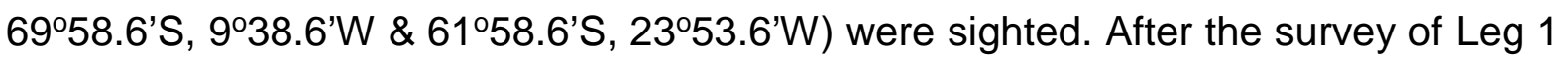
ended, two southern elephant seals and a leopard seal were sighted the following day on different ice floes in the immediate vicinity of Southern Thule. The ship then remained in open water for the following two weeks, before re-entering the pack ice on 12 January 2016 for Leg 2 (Fig. 1B).

\section{Ship-board census - Leg 2}

The census of 12 January (24.0 linear nm; $44.45 \mathrm{~km}$ ) was taken in the contiguous pack ice located immediately off the Princess Martha Coast in the same, but much reduced, ice mass where the ship-board censuses of Leg 1 were conducted earlier (Fig. 1B). Within transect during survey hours, pack ice seals were encountered in a ratio of $85.7 \%$ crabeater seals $(n=30), 11.4 \%$ Ross seals $(n=4)$ and $2.9 \%$ leopard seals $(n=1)$, with no Weddell seals sighted. On census, we encountered Ross seals at a density of 0.77 individuals per $\mathrm{nm}^{-2}$ (Table 1 ). Off census (no transect censusing conducted at the time), at least 21 different Ross seals were encountered (each captured temporarily to deploy data loggers and/or obtain biopsy samples) from 13-14 January, and 21-27 January, during a dedicated search for Ross seals in the same area. We observed one Weddell seal and one leopard seal on 14 January. Pack-ice cover was present in every interval (15 min) of travel with mean ( \pm standard deviation) percentage cover of $93.8 \pm 20.5 \%$ (range $20-100 \%$ ). 
Table 1: Summary of ship-board censuses of Antarctic pack ice seals during the peak diel haulout period in the eastern Weddell Sea off the Princess Martha Coast at comparable times during mid austral summers.

\begin{tabular}{|c|c|c|c|c|c|c|c|}
\hline \multirow[t]{2}{*}{ References } & \multirow[t]{2}{*}{$\begin{array}{l}\text { Census } \\
\text { dates }\end{array}$} & \multirow[t]{2}{*}{ Locality } & \multirow[t]{2}{*}{$\begin{array}{l}\text { Total } \\
\text { area } \\
\left(\mathrm{nm}^{2}\right)\end{array}$} & \multicolumn{4}{|c|}{ Seals $\left(\mathrm{nm}^{-2}\right)$} \\
\hline & & & & Crabeater & Ross & Leopard & Weddell \\
\hline $\begin{array}{l}\text { Hall-Martin } \\
(1974)\end{array}$ & $\begin{array}{l}17 / 01- \\
02 / 02 / 1974\end{array}$ & $1-6^{\circ} \mathrm{W}$ & 54.1 & 2.46 & 0.74 & 0.04 & 0.02 \\
\hline $\begin{array}{l}\text { Wilson } \\
\text { (1975) }\end{array}$ & $\begin{array}{l}\text { 20/01 - } \\
30 / 01 / 1975\end{array}$ & $2-4^{\circ} W$ & 45.4 & 5.24 & 2.91 & 0.07 & 0.35 \\
\hline $\begin{array}{l}\text { Condy } \\
\text { (1976) }\end{array}$ & $\begin{array}{l}19 / 01- \\
14 / 02 / 1976\end{array}$ & $9^{\circ} \mathrm{W}-3^{\circ} \mathrm{E}$ & 56.1 & 5.12 & 0.84 & 0.14 & 0.52 \\
\hline $\begin{array}{l}\text { Condy } \\
\text { (1977) }\end{array}$ & $\begin{array}{l}\text { 20/01/ - } \\
08 / 02 / 1977\end{array}$ & $3^{\circ} \mathrm{W}-9^{\circ} \mathrm{E}$ & 83.7 & 4.11 & 0.45 & 0.06 & 0.06 \\
\hline $\begin{array}{l}\text { Present } \\
\text { study }\end{array}$ & 12/01/2015 & $2^{\circ} \mathrm{W}$ & 5.2 & 5.77 & 0.77 & 0.19 & 0.00 \\
\hline
\end{tabular}




\section{Discussion}

Several sources of bias and uncertainty underlie pack ice seal abundance estimates derived from ship-board strip- and line transects (summarised in Southwell et al. 2012). Despite the drawbacks, we opted for a simple methodological approach, as it was comparable to earlier ship-board surveys (summarised in Bester and Odendaal 2000).

During Leg 1, we encountered only crabeater seals on the survey, at exceptionally low densities $\left(1.03 \mathrm{~nm}^{-2}\right)$ less than half of the lowest on record for ship-board surveys in the eastern Weddell Sea in mid-summer which varied between $2.46 \mathrm{~nm}^{-2}$ and 5.24 $\mathrm{nm}^{-2}$ (see Table 1). Over the entire 16-day period (including $24 \mathrm{~h}$ vigils when the ship was in transit through pack ice), other than crabeater seals, we encountered only one Weddell seal, one leopard seal, and two Ross seals. The Ross seals were on consolidated pack ice in one instance and a vast ice floe in the other (24-27 December 2015). Together with the reported presence of two Ross seals off the fast ice at 72030'S, 18\% near Austasen on 25 December 2015 (sighted during helicopter reconnaissance of pack ice off the RV Polarstern - M. Schröder pers. comm.), these sightings conform to Ross seal sightings on 22 December 1991 (Bester et al. 1995) within the eastern Weddell Sea. Furthermore, the Perennial Acoustic Observatory in the Antarctic Ocean (PALAOA) located on the Ekström Ice shelf $\left(70^{\circ} 31^{\prime} \mathrm{S}, 8^{\circ} 13^{\prime} \mathrm{W}\right)$, $15 \mathrm{~km}$ distant from Neumayer III Station, hydroacoustically recorded Ross seal calls as early as 16 December 2006 (van Opzeeland et al. 2010). Moreover, in the Ross Sea this species was already present end-December 2010 (Arcalís-Planas et al. 2015) in early stages of moulting, and therefore must have arrived some days earlier as the Ross seal moult lasts less than a week once started (Blix and Nordøy 2007).

The early season densities of crabeater seals $\left(1.03 \mathrm{~nm}^{-2}\right)$ were much less than the ship-board recorded, crabeater seal density (2.46 nm-2) of Hall-Martin (1974). This is the probable result of (a) the later census dates (January/February) of former years (see Table 1) when the extent of seasonal pack ice cover would have diminished, and (b) the inverse relationship between pack ice cover and seal densities (Eklund and Atwood 1962; Bester et al. 1995). Furthermore, late season density of crabeater seals $\left(5.77 \mathrm{~nm}^{-2}\right)$, although measured over a very small area in the present study (Table 1), was similar to the higher range of densities (4.11-5.24 $\mathrm{nm}^{-2}$ ) recorded by Wilson (1975) and Condy $(1976,1977)$, at a comparable time (January/February), in previous years. 
The relatively high densities $\left(0.45-2.91 \mathrm{~nm}^{-2}\right)$ and percentage species contribution (9.7-22.4\%) of Ross seals encountered (ship-board censuses, same area and time of season) during the early 1970s (Hall-Martin 1974; Condy 1976, 1977), were similar $\left(0.77 \mathrm{~nm}^{-2} ; 11.4 \%\right)$ in the present study. Although only a relatively small census area $\left(5.20 \mathrm{~nm}^{2}\right)$ was searched on 12 January 2016, producing four Ross seals, a further 22 different Ross seals were found in mid- to late-January 2016, in the same general area, crabeater seals still predominating (Bester et al. 1995, 2002; Gurarie et al. 2017; this study).

We conclude that censusing of Ross seals is preferably carried out in late January/early February when the species' haulout probability is at its maximum and the seals are gathered in the limited summer pack ice to moult (Blix and Nordøy 2007; this study). A continued relatively high abundance of Ross seals, off the Princess Martha Coast in the eastern Weddell Sea is suggested (this study). This is an important conclusion should the proposed CCAMLR Marine Protected Area (MPA) in the Weddell Sea (Teschke et al. 2016) be established, given the dearth of Ross seal sightings in other regions of the Weddell Sea (Erickson et al. 1969; Siniff et al. 1970; Erickson 1984; Erickson and Hanson 1990; Bornemann et al. 2014).

\section{Acknowledgements}

The Officers and Crew of the MV SA Agulhas II extended every possible courtesy to us in support of our research objectives. Chief Scientist, Dr Thato Mtshali, is thanked for his support, and the Department of Environment Affairs' Co-ordinating Officer (DCO) and Deputy DCO, for facilitation. The Department of Environment Affairs (DEA) for logistical support within South African National Antarctic Programme (SANAP), and the Department of Science and Technology (DST), through the National Research Foundation (NRF), for funding this project. This work is based on the research supported by the NRF (Grant Number 93088) and the authors acknowledge that opinions, findings and conclusions expressed in this publication generated by the NRF supported research is that of the authors, and that the NRF accepts no liability whatsoever in this regard. 


\section{Compliance with Ethical Standards}

The University of Pretoria Animal Ethics Committee cleared the procedures of this project (Number EC082-15) under South African Department of Environmental Affairs Permit 04/2015-16, pursuant to the provisions of Article 3 of the Protocol on Environmental Protection to the Antarctic Treaty, and Annex II and Annex V (Article 10(2)).

\section{References}

Arcalís-Planas A, Sveegaard S, Karlsson O, Harding KC, Wahlin A, Harkonen T, Teilmann J (2015) Limited use of sea ice by the Ross seal (Ommatophoca rossii), in Amundsen Sea, Antarctica, using telemetry and remote sensing data. Polar Biol 38:445-461

Bester MN (2014) Ross Seal. In: Hund A (ed) Antarctica and the Arctic Circle: A Geographic Encyclopedia of the Earth's Polar Regions, Volume 2, ABC-CLIO Inc., Santa Barbara, pp 618-620

Bester MN, Erickson AW, Ferguson JWH (1995) Seasonal change in the distribution and density of seals in the pack ice off Princess Martha Coast, Antarctica. Antarct Sci 7:357-364

Bester MN, Ferguson JWH, Jonker FC (2002) Population densities of pack ice seals in the Lasarev Sea, Antarctica. Antarct Sci 14:123-127

Bester MN, Odendaal PN (2000) Abundance and distribution of Antarctic pack ice seals in the Weddell Sea. In: Davison W, Howard-Williams C, Broady P (eds) Antarctic Ecosystems: Models for Wider Ecological Understanding, Caxton Press, Christchurch, pp 51-55

Blix AS, Nordøy ES (2007) Ross seal (Ommatophoca rossii) annual distribution, diving behaviour, breeding and moulting, off Queen Maud Land, Antarctica. Polar Biol 30:1449-1458

Bornemann H, Oosthuizen WC, Bester MN (2014) Seal research at the Filchner Outflow System (SEAFOS). In: Knust R, Schröder M (eds) The Expedition PS82 of 
the Research Vessel POLARSTERN to the southern Weddell Sea in 2013/2014 AWI Rep Polar Mar Res 680:115-135

Cavalieri DJ, Parkinson CL, Gloersen P, Zwally HJ (1996, updated yearly) Sea Ice Concentrations from Nimbus-7 SMMR and DMSP SSM/I-SSMIS Passive Microwave Data, Version 1. Boulder, Colorado USA. NASA National Snow and Ice Data Center Distributed Active Archive Center. doi: http://dx.doi.org/10.5067/8GQ8LZQVLOVL. [Date Accessed: 2016-12-27].

Condy PR (1976) Results of the third seal survey in the King Haakon VII Sea, Antarctica. S Afr J Antarct Res 6:2-8

Condy PR (1977) Results of the fourth seal survey in the King Haakon VII Sea, Antarctica. S Afr J Antarct Res 7:10-13

Eklund CR, Atwood EL (1962) A population study of Antarctic seals. J Mamm 43:229238

Erickson AW (1984) Aerial census of seals, whales and penguins in the pack ice of the northwestern Weddell Sea, November 1983. Antarct J US 19:121-124

Erickson AW, DR Cline, Hoffman RJ (1969) Population study of seals in the Weddell Sea. Antarct J US 4:99-100

Erickson AW, Hanson MB, Kehoe DM (1983) Population densities of seals and whales observed during the 1983 circumnavigation of Antarctica by the USCGC Polar Star. Antarct J US 18:163-166

Erickson AW, Bledsoe LJ, Hanson MB (1989) Bootstrap correction for diurnal activity cycle in census data for Antarctic seals. Mar Mamm Sci 5:29-56

Erickson AW, Hanson MB (1990) Continental estimates and population trends of Antarctic ice seals. In: Kerry K, Hemper G (eds) Antarctic ecosystems: ecological change and conservation, Springer, New York, pp 253-264

Erickson AW, Siniff DB, Harwood J (1993) Estimation of population sizes. In: Laws RM (ed) Antarctic seals: Research methods and techniques, Cambridge University Press, Cambridge, pp 29-45 
Gurarie E, Bengtson JL, Bester MN, Blix AS, Bornemann H, Cameron M, Nordøy ES, Plötz J, Steinhage D, Boveng P (2017) Distribution, density and abundance of Antarctic ice seals in Queen Maud Land and the eastern Weddell Sea. Polar Biol 40:1149-1165.

Hall-Martin AJ (1974) Observations on population density and species composition of seals in the King Haakon VII Sea, Antarctica. S Afr J Antarct Res 4:34-39

Laws RM (1993) Identification of species. In: Laws RM (ed) Antarctic seals: Research methods and techniques, Cambridge University Press, Cambridge, pp 1-28

Van Opzeeland I, Van Parijs S, Bornemann H, Frickenhaus S, Kindermann L, Klinck H, Plötz J, Boebel O (2010) Acoustic ecology of Antarctic pinnipeds. Mar Ecol Prog Ser 414:267-291

Siniff DB, Cline DR, Erickson AW (1970) Population densities of seals in the Weddell Sea, Antarctica, in 1968. In: Holdgate MW (ed.) Antarctic Ecology, Academic Press, London, pp 377-394

Southwell C, Bengtson J, Bester MN, Blix AS, Bornemann H, Boveng P, Cameron M, Forcada J, Laake J, Nordøy E, Plötz J, Rogers T, Southwell D, Steinhage D, Stewart BS, Trathan P (2012) A review of data on abundance, trends in abundance, habitat use and diet of ice-breeding seals in the Southern Ocean. CCAMLR Sci 19:49-74

Teschke K, Beaver D, Bester M, Bombosch A, Bornemann H et al (2016) Scientific background document in support of the development of a CCAMLR MPA in the Weddell Sea (Antarctica), Part A: General context of the establishment of MPAs and background information on the Weddell Sea MPA planning area. CCAMLR WG-EMM15/38, 89 pp

Wilson VJ (1975) A second survey of seals in the King Haakon VII Sea, Antarctica. SA J Antarct Res 5:31-36 